\title{
Anticancer potential of Siddha formulations against oral cancer cell line in vitro
}

\author{
Priyanka Ganapathy ${ }^{1,2}$, Kayalvizhi Elumalai ${ }^{1 *}$, Madan Kumar Arumugam ${ }^{3 *}$, Chinmayi Sri Amulya ${ }^{3}$ and Rajajeyakumar Manivel $^{4}$ \\ ${ }^{1}$ Meenakshi Medical College Hospital and Research Institute, Kanchipuram, Tamil Nadu, India \\ ${ }^{2}$ Ragas Dental College and Hospital, Uthandi, Chennai, Tamil Nadu, India \\ ${ }^{3}$ Cancer Biology Lab, Molecular and Nanomedicine Research Unit, Sathyabama Institute of Science and Technology, Chennai, Tamil Nadu, India \\ ${ }^{4}$ Department of Physiology, Trichy SRM Medical College Hospital and Research Centre, Trichy, Tamil Nadu, India
}

\begin{abstract}
Treatment of cancer without any side-effects is still a challenge in the medical system. This leads to an increasing search for improved anticancer drugs. Plant products have been used as a traditional medicine for thousands of years as it has been drawing a great deal of attention to overcome cancer. The main objective of this study is to evaluate and compare the anticancer effect of MahaVallathy Leghiyam (MVL) and Neeradi Muthu Vallathy Leghiyam (NMVL) against human oral cancer (KB) cells. Different concentrations of aqueous extracts of MVL and NMVL were subjected to cytotoxic study. The antiproliferative effects were determined by 3-(4,5-dimethylthiazol-2-yl)-2,5-diphenyltetrazolium bromide (MTT) assay and IC50 concentration was found at $3.25 \mathrm{mg} / \mathrm{mL}$ for $\mathrm{MVL}$ and $1.25 \mathrm{mg} / \mathrm{mL}$ for NMVL, also apoptotic activities were studied by PI and AO/EB dual staining. The results acquired from the comparative in-vitro studies on KB cell lines revealed that the unique Siddha medicine NMVL has more potent anticancer activity compared to MVL. There was an increase in the cell growth inhibition when treated with NMVL at lower concentration compared to MVL. The current investigation suggested that the phyto constituents of NMVL are responsible for anticancer activity. Thus, the long-term consumption of NMVL could be considered and promoted as an adjuvant therapy for treating various malignancies.
\end{abstract}

\section{Introduction}

One of the most distressing diseases according to recent report is oral cancer and it ranks as third most common cancers in India, after cervical and breast cancer in female [1]. Hence, it is considered as a frivolous problem by the public officials, medical centres and private hospitals [2]. National Cancer Registry Programme (NCRP) reported Bhopal males precede Ahmedabad men by showing highest age-adjusted rate for mouth cancers [3]. Cigar smoking and alcohol consumption are the major risk factors in western countries, while chewing areca nut, betel-quids and smoking are major risk factors in South Asia, Southeast Asia and Taiwan [4]. The disease is highly allied to establish cultural risk factors that have been acquired traditionally by these populations to these specific risk factors [5]. Oral cancer is any malignancy neoplasm that appears as an abnormal growth within the oral cavity which includes buccal mucosa (cheek lining), gingiva, palate or the tongue, floor of the mouth and lip. Progression of OSCC is a multi-step process involving DNA fragmentation, membrane blebbing, chromatin condensation, genes related to the growth control, apoptosis, DNA damage response and other cellular regulators [6].

A quotidian treatment modality that has been used to control advanced stages of malignancies is Chemotherapy as it is known for its speedy prophylactic action against possible metastasis [7]. Several immune-modulating agents, chemotherapeutic drugs and cytotoxic drugs are available in Western medicine to treat various cancers. Apart from being enormously expensive, these drugs are associated with serious after effects. Ayurveda and polyherbal siddha preparations are emerging trends in curing many cancers which are being used by $80 \%$ of the World population, especially in developing countries. Siddha and Ayurveda are the traditional Indian system of medicines that has been successful since antediluvian times using natural herbal preparations, that can suppress and act against various tumors. Variety of them is being screened worldwide to validate their use as anti-cancerous drugs [8]. The phytochemical screening on quantitative analysis showed that the elements of MVL and NMVL are rich in popular phytochemical constituents such as flavonoids, terpenoids, carbohydrates, steroids and alkaloids. However, only limited scientific investigations has been carried out on anticancer activity of these two siddha formulations. The ability of these siddha formulations to efficiently inhibit oral cancer cell growth by promoting a competent rate of apoptosis is yet to be discovered and hence in this study, an attempt to congregate the anti-proliferative and anticancer potential of MVL and NMVL in their aqueous states have been closely monitored through an in-vitro analysis

\section{Materials and methods}

\section{Reagents}

Dulbecco's Modified Eagle's Medium (DMEM), Fetal Bovine Serum (FBS), Trypsin methylthiazolyl diphenyl- tetrazolium bromide (MTT)

${ }^{\star}$ Correspondence to: Kayalvizhi Elumalai, Associate Professor, Department of Physiology, Meenakshi Medical College Hospital and Research Institute, Kanchipuram, Chennai-600 119, Tamil Nadu, India, Tel: 8870365116; E-mail: kayalgkbs@gmail.com

Madan Kumar Arumugam, Scientist 'C', Cancer Biology Lab, Molecular and Nanomedicine Research Unit, Sathyabama Institute of Science and Technology, Tamil Nadu, India, Tel: 91 9942110146; E-mail: madankumarbio@gmail.com

Key words: Neeradi muthu vallathy, Mahavallathy leghiyam, KB cells, MTT, apoptosis, proliferation

Received: April 09, 2019; Accepted: May 20, 2019; Published: May 23, 2019 
and Dimethyl sulfoxide (DMSO), Propidium iodide (PI), Acridine Orange (AO) and Ethidium bromide (EB) were procured from HiMedia Laboratories, other chemicals and reagents were obtained from Sigma Aldrich Mumbai.

\section{Preparation of MVL and NMVL}

MVL and NMVL were procured form Indian Medical Practitioners Co-operative Pharmacy and Stores Ltd., (IMPCOPS, Thiruvanmiyur, Chennai, India), an authoritative source of Indian medicines (http:// www.impcops.org/), and its composition as per the ancient scripts [9].

\section{Extract preparation}

The MVL and NMVL were dissolved in different grading of solvent system, to check the effective solubility. Based on the solubility test, it was confirmed that formulations were soluble in water to employ aqueous extract, and it was used for future studies.

\section{Cell culture}

Human oral cancer KBcell lines were obtained from National Center for Cell Science (NCCS), Pune, India. The cells were nurtured in T25 flasks at $37^{\circ} \mathrm{C}$ in Dulbecco's Modified Eagle Media supplements along with 10\% FBS (Sigma-Aldrich, St. Louis, Mo, USA),100 units/ $\mathrm{mL}$ penicillin $\mathrm{G}$ and $100 \mu \mathrm{g} / \mathrm{mL}$ streptomycin as antibiotic (Himedia, Mumbai, India). For all the experiments the cells were maintained in $100-\mathrm{mm}$ culture dishes (Nunc) at humidified $5 \% \mathrm{CO}_{2} / 95 \%$ atmosphere air (Heraeus, Hanau, Germany). Cells were sub cultured every 2-3 days to improve the cell number and the cell population was assessed by using haemocytometer, a standard procedure for cell counting.

\section{Cell proliferation assay}

MTT assay was carried out following as per the method of Safadi et al. [10]. Cells $\left(1 \times 10^{5} /\right.$ well $)$ were plated in 24 -well plates and incubated in $37^{\circ} \mathrm{C}$ with $5 \% \mathrm{CO}_{2}$ condition. After the cell reached the confluence, various concentrations $(25,12.5,6.5,3.25,1.625,0.81,0.4,0.1 \mathrm{mg} / \mathrm{mL})$ of MVL and $(25,12.5,6.5,3.25,2.5,1.25,0.75,0.35,0.18$ and $0.9 \mathrm{mg} /$ $\mathrm{mL}$ ) of NMVL were treated and incubated for $24 \mathrm{hrs}$ and $48 \mathrm{hrs}$. After incubation, the sample was removed from the well and washed with phosphate-buffered saline (PBS) (pH 7.4). $100 \mu \mathrm{L} /$ well $(5 \mathrm{mg} / \mathrm{mL})$ of 0.5\% 3-(4,5-dimethyl-2-thiazolyl)-2,5-diphenyl--tetrazolium bromide (MTT) was added and incubated for 4 hours. After incubation, $1 \mathrm{~mL}$ of DMSO was added in all the wells. The absorbance at $570 \mathrm{~nm}$ was measured with UV- Spectrophotometer using DMSO as the blank. Measurements were performed and the concentration required for a $50 \%$ inhibition (IC50) was determined graphically. The $\%$ cell viability was calculated using the following formula:

$$
\% \text { inhibition }=\frac{\text { Mean OD of untreated cells }- \text { Mean OD of treated cells }}{\text { Mean OD of untreated cells }} \times 100
$$

Graphs were plotted using \% of cell viability at Y-axis and concentration of the sample in X-axis. Cell control and sample control were included in each assay to compare the full cell viability assessments. Based on MTT assay, IC $_{50}$ values obtained were $3.25 \mathrm{mg} / \mathrm{mL}$ for MVL and $1.25 \mathrm{mg} / \mathrm{mL}$ for NMVL respectively, which were further employed to assess their extent of effects on nucleus, morphology and apoptotic effects of DNA.

\section{PI staining}

Propidium iodide (PI) staining was carried out by the method of Sirpu Natesh et al. [11]. KB cells were plated at a density of $5 \times 10^{4}$ in 6-well plates. They were allowed to grow at $37^{\circ} \mathrm{C}$ in a humidified $\mathrm{CO}_{2}$ incubator until they are $70-80 \%$ confluent. Then cells were treated with $3.25 \mathrm{mg} / \mathrm{mL}$ for MVL and $1.25 \mathrm{mg} / \mathrm{mL}$ for NMVL for $24 \mathrm{hrs}$ and $48 \mathrm{hrs}$. Culture medium was aspirated from each well and cells were gently rinsed twice with PBS at room temperature, before fixing in methanol: acetic acid (3:1 v/v) for $10 \mathrm{~min}$, and stained with $50 \mu \mathrm{g} / \mathrm{mL}$ PI for $20 \mathrm{~min}$. Nuclear morphology of apoptotic cells with condensed/ fragmented nuclei was examined by fluorescence microscopy and at least $1 \times 10^{3}$ cells were counted for assessing apoptotic cell death.

\section{AO/EB dual staining}

Acridine orange/Ethidium bromide staining was carried out by the method of Sirpu Natesh et al. [12]. KB cells were plated at a density of $1 \times 10^{4}$ in 6 -well plates. They were allowed to grow at $37^{\circ} \mathrm{C}$ in a humidified $\mathrm{CO}_{2}$ incubator until establishing $70-80 \%$ confluency. Then cells were treated with $3.25 \mathrm{mg} / \mathrm{mL}$ for MVL and $1.25 \mathrm{mg} / \mathrm{mL}$ for NMVL (selected based on the $\mathrm{IC}_{50}$ concentration) of the test drugs for $24 \mathrm{hrs}$ and $48 \mathrm{hrs}$. The culture medium was aspirated from each well and cells were gently rinsed twice with PBS at room temperature. Then equal volumes of cells from control and drugs treated were mixed with $100 \mu \mathrm{L}$ of dye mixture (1:1) of ethidium bromide and acridine orange and viewed immediately inverted fluorescence microscope at $20 \times$ magnification. A minimum of 300 cells were counted in each sample at two different fields. Three hundred cells per sample were counted at each time points such as 24 hrs and 48 hrs. The cells were scored as viable or dead, and if dead, whether by apoptosis or necrosis as judged from nuclear morphology and cytoplasmic organization. The percentage of apoptotic and necrotic cells were then calculated. Morphological features of interest were photographed and calculated,

$$
\% \text { of apoptotic cells }=\frac{\text { total number of apoptotic cells }}{\text { total number of cells counted }} \times 100
$$

Viable cells with organized structure were identified by green fluorescence. Early apoptosis were presented with highly condensed or fragmented yellow chromatins. The same, condensation and fragmentation with orange chromatins were marked as late apoptosis. Bright orange chromatin in round nuclei was appreciated in necrotic cells. Membrane blebbing also indicates apoptosis.

\section{Statistics}

Numerical data are expressed as mean \pm standard deviation (SD). Statistical differences were evaluated by a one-way analysis of variance (ANOVA) using statistical package for social sciences (SPSS) software for window 9 Version 11.5 (SPSS) Inc., Chicago, Ill, USA). Post Hoc test was performed for comparisons using the least significant difference (LSD) test, were considered statistically significant when $\mathrm{P}<0.05$.

\section{Results \\ Cell viability Assay}

$\mathrm{KB}$ cells were incubated and tested with several tetrazolium salts. Finally only the pale yellow MTT reagent generated the most expected results by producing dark blue formazan. MTT reaction product was only partially soluble in the medium, therefore an alcohol (isopropanol - acid-alcohol mixture) was employed to dissolve the formazan to produce a homogenous solution suitable for measuring the optical density. Due to $\mathrm{pH}$ changes, a variable colour of phenol red was produced by normal tissue culture medium which interfered with the wavelength of blue MTT. At the end of the assay this was bypassed by converting the phenol red to absolute yellow acidic form. After the final procedure, MTT cleavage was achieved after $4 \mathrm{~h}\left(37^{\circ} \mathrm{C}\right)$. The OD was measured at 
$630 \mathrm{~nm}$ using reference value and $570 \mathrm{~nm}$ as test wavelengths. When exposed to MVL and NMVL under different concentrations both the formulations inhibited $\mathrm{KB}$ cells proliferation in time and dosedependent manner. Further, KB cells were notably sensitive to NMVL as it could affect the cell viability even at a concentration notably lesser than the MVL. The $50 \%$ inhibitory concentration $\left(\mathrm{IC}_{50}\right)$ of drug value was obtained at $3.25 \mathrm{mg} / \mathrm{mL}$ for MVL and $1.25 \mathrm{mg} / \mathrm{mL}$ for NMVL. However when the concentration of the drugs increased, there was an increase in cell growth inhibition.

The results in Figures 1 and 2 indicates that absorbance is directly proportional to the number of cells when treated with series of test drug dilutions showing remarkable intensity of the cell growth inhibition. Thus NMVL acted most efficaciously on the cell population even at lesser concentrations, while MVL comparatively produced moderate cytotoxic effects only. MTT assay is also capable of detecting very small number of living cells, as the actual cells fail to absorb even at $1 \times 10^{6}$ cells/mL. Doxyrubcin was treated as a positive control.

\section{Morphological changes using Phase contrast inverted microscope}

The apoptogenic feature of the two test formulations were investigated by observing the morphological changes in $\mathrm{KB}$ cells at two different set points to check for its efficacy on hourly basis. The damaged cells typically displayed cell shrinkage, nuclear condensation, membrane blebbing, chromatin cleavage and formation of pyknotic bodies of condensed chromatin [13,14]. These features are typical hallmark changes appreciated in cell deaths which are widely applied to quantify and identify apoptosis [15]. The morphological changes were appreciated crystal clear by viewing under an Inverted phase contrast microscope.

After seeding the cell lines with the $\mathrm{IC}_{50}$ dose of NMVL $(3.25 \mathrm{mg} /$ $\mathrm{mL})$ and MVL $(1.25 \mathrm{mg} / \mathrm{mL})$ the test compounds for 24 and $48 \mathrm{hrs}$, structural alterations in $\mathrm{KB}$ cells were observed in comparison to control cells (Figure 3). Visualizing the (untreated) control cells, its original adherent property remained unchanged by clinging to their culture dishes without floating. The cells were impregnated with perfect nucleoli without any structural distortions. After treating with MVL and NMVL, revealed remarkable morphological changes such as rounding, shrinkage presenting irregular shape of the plasma membrane resulting in blebbing and lost contact with cells nearby. MVL acted rationally in between set hours ( 24 and 48 hrs) while as NMVL treated plates showed with standard morphological changes such as echinoid spikes

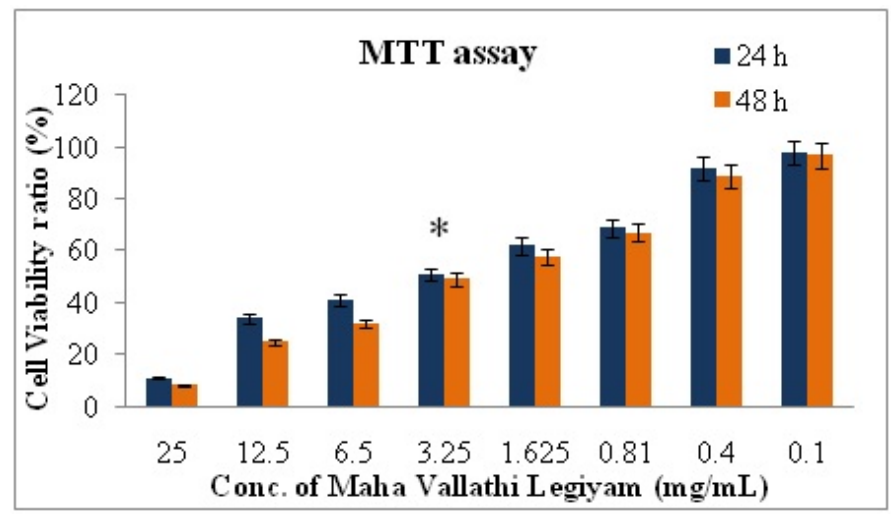

Figure 1. The percent cell viability of KB cells measured by MTT assay at $24 \mathrm{hrs}$ and $48 \mathrm{hrs}$ in the treatment with different concentration of MVL. Values are expressed as means $\pm S D$ of at least three independent experiments, $\mathrm{P}<0.01$ as compared with their respective control. $\mathrm{IC}_{50}$ concentration was found at $3.25 \mathrm{mg} / \mathrm{mL}$

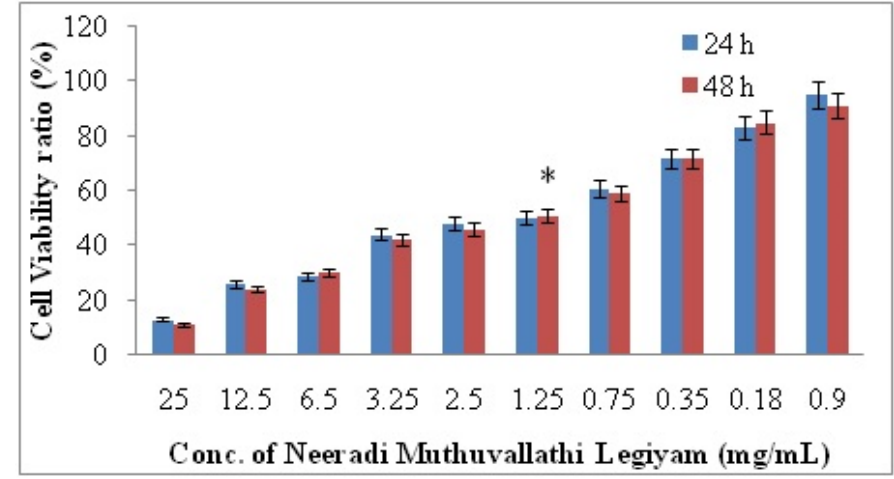

Figure 2. The percent cell viability of KB cells measured by MTT assay at 24 hrs and 48 hrs in the treatment with different concentration of NMVL. Values are expressed as means $\pm \mathrm{SD}$ of at least three independent experiments, $\mathrm{P}<0.01$ as compared with their respective control. $\mathrm{IC}_{50}$ concentration was found at $1.25 \mathrm{mg} / \mathrm{mL}$.

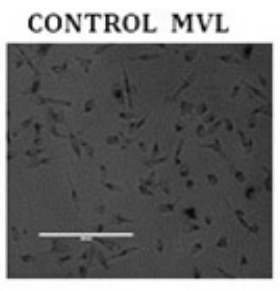

CONTROL NMVL

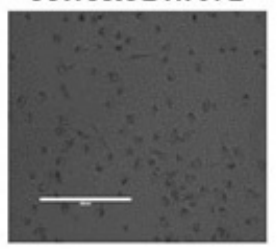

24Hrs MVL

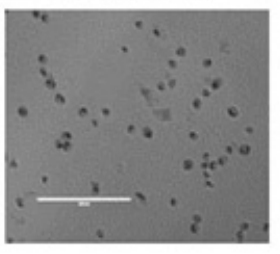

24Hrs NMVL

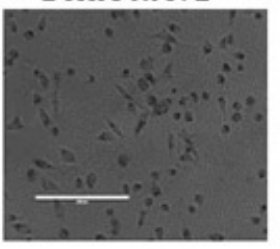

$48 \mathrm{Hrs}$ MVL

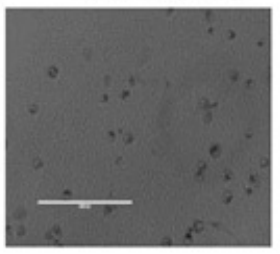

48Hrs NMVL

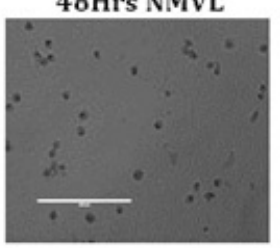

Figure 3. Morphological changes of KB cells under Phase contrast microscopy. Control $\mathrm{KB}$ cells showed uniform monolayer. Incubation of KB cells with MVL and NMVL for 24 and 48 hrs showed remarkable morphological changes in plates. The MVL and NMVL treated cells showed condensed nuclei, cell shrinkage and membrane blebbing, apoptotic bodies, bubbling with echinoid spikes. The percentage of confluency of the cells notably decreased to $50 \%$ and $74 \%$ at $24,48 \mathrm{hrs}$ of MVL treatment, whereas, in NMVL treated samples it was $31 \%$ and $75 \%$ at 24,48 hrs respectively

of the surface of the apoptotic cell bodies with gradual decremental cell number especially after $48 \mathrm{hrs}$.

\section{Morphological observations of human oral cancer KB cell lines using fluorescence microscope}

Significant morphological changes were observed in the nuclei of KB cells after 24 and $48 \mathrm{hrs}$ exposure to MVL and NMVL. From Figure 4, the control cells appeared oval and intact. Cells dosed with both NMVL and MVL showed cell deflation, chromatin condensation, multiple genomic DNA fragmentations, distorted apoptotic bodies with cell membrane shape deformities and decrease in cell number. These observations were considered as morphological hallmarks of the terminal stage of apoptosis. KB cells response to NMVL was well marking compared to MVL. Apoptosis enhanced in NMVL treated groups showing prominent cell decrement at 48 hours treatment compared to MVL.

The percentage of apoptotic nuclei after treating with $1.25 \mathrm{mg} / \mathrm{mL}$ NMVL (Figure 4) was more than in $3.25 \mathrm{mg} / \mathrm{mL}$ MVL treated group (Figure 4), while appreciating the apoptotic changes on the DNA, the 
fluorescence images with phase contrast images were merged to analyze the morphological changes over the cell membrane such as loss of integrity of the plasma membrane [16].

\section{MVL and NMVL impact on morphology through AO/EB staining after apoptosis}

Morphological features of apoptosis were further scrutinized by viewing through fluorescence microscopy after AO/EB dual staining. Figure 5 represents control, MVL and NMVL treated when the cell lines were administered with $3.25 \mathrm{mg} / \mathrm{mL}$ MVL and 1.25 $\mathrm{mg} / \mathrm{mL}$ NMVL. Staining with $\mathrm{AO}$ and $\mathrm{EB}$ revealed condensed state of chromatin, fragmented nucleus, abnormal shape and size in $\mathrm{KB}$ cells when treated with 24 and $48 \mathrm{~h}$ while the control cells exhibited a normal cell morphology characterized by a diffused chromatin structure and whereas for light green (EB) staining shows pronounced discriminative results. The percentage of apoptotic cells after $24 \mathrm{hrs}$ and $48 \mathrm{hrs}$ treatment with $3.25 \mathrm{mg} / \mathrm{mL}$ of MVL and $1.25 \mathrm{mg} / \mathrm{mL}$ of NMVL
CONTROL MIVL
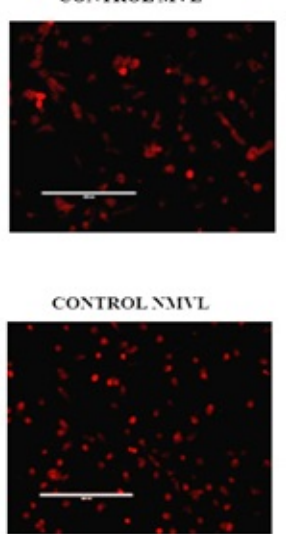

$24 \mathrm{Hrs}$ MVL

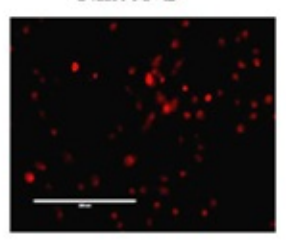

24 Hrs MNVL

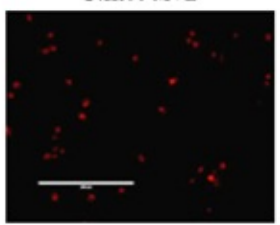

4 SHrs MIV L

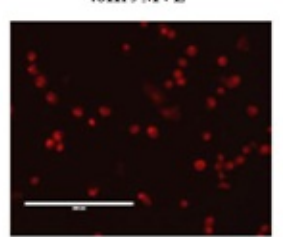

$48 H$ s NOTL

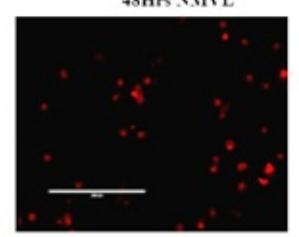

Figure 4. Morphological changes of KB cells under fluorescence microscopy (PI staining) Representative composite images show morphological changes of control, MVL and NMVL treated $\mathrm{KB}$ cells by fluorescence microscopy, after staining with propidium iodide. The percentage of apoptotic nuclei after 24 and $48 \mathrm{hrs}$ treatments with MVL and NMVL $(\mathrm{p} \leq 0.05$ ) were $41 \%$ and $61 \%$ respectively, as revealed by nuclear condensation and fragmentation as shown by arrows. Whereas NMVL apoptotic activity enormously increased after $48 \mathrm{hrs}$ revealed as $75 \%$

\section{CONTORL MVL}

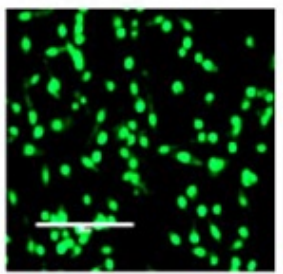

CONTORL NMVL

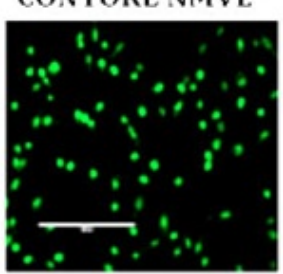

MVL 24Hrs

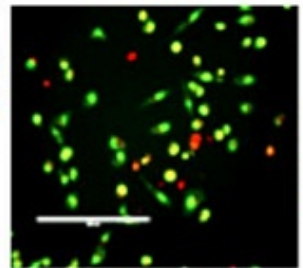

NMVL 24Hrs

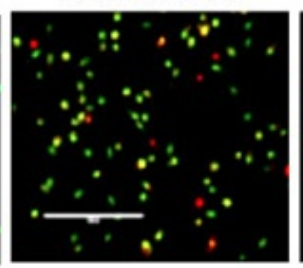

MVL $48 \mathrm{Hr}$

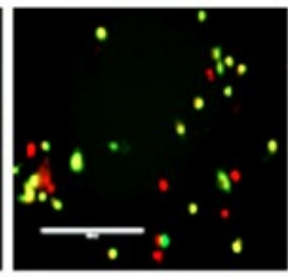

NMVL $48 \mathrm{Hrs}$

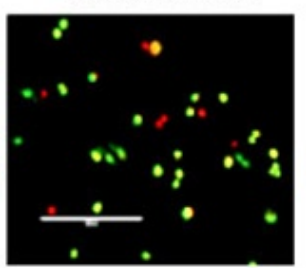

Figure 5. AO/EB staining of KB oral cancer cells treated with MVL and NMVL for 24 and $48 \mathrm{hrs}$. AO/EB staining of MVL treatment for $48 \mathrm{hrs}$ shows early apoptosis with yellow fluorescent nuclei. NMVL for $48 \mathrm{hrs}$ shows late apoptotic cells with orange/red fluorescent nuclei compared with control KB cells. increased $(p \leq 0.05)$ drastically to $41 \%$ and $61 \%$ in case of MVL and $31 \%$ and $75 \%$ respectively.

\section{Discussion}

Oral and tongue cancer is an inordinate, complex multifocal process that mainly halted in three main anatomical sites of an oral cavity by causing several genetic alterations [17]. Chemotherapy, an expensive, most intended cancer treatment not only provoked serious side effects but also enormously worsens the financial stability of a family thereby affects the overall province of a country. Ever since olden days, herbal based medicines are most preferred for curing various challenging ailments $[18,19]$. Currently indigenous medicinal therapy is commonly in practice by CAM practitioners. MVL constitutes more than 34 different botanicals while NMVL bears more than 20 daily used herbs in it and was used against various chronic ailments. So far studies reporting anticancer property of these two drugs are lacking. Therefore, their crude and fractioned extracts were employed to evaluate their cytotoxicity and antiproliferative activity on KB cell lines.

The outcome of cytotoxicity assay using MTT in this study is clearly revealed through the respective $\mathrm{IC}_{50}$ dosage values. Crude extracts of both test drugs were employed to know whether the formulation is toxic to even native cells. MTT results of MVL revealed $85 \%$ of viability at $1.25 \mathrm{mg} / \mathrm{mL}$ concentration and $50 \%$ viability at 3.25 $\mathrm{mg} / \mathrm{mL}$ when compared to the standard anti-cancer drug Doxyrubcin. Previous reports supports our current outcome that the components of NMVL possess anticancer, antioxidant, anti-inflammatory and analgesic properties [20-23]. NMVL could exert 50\% viability even at the minimum concentration, while MVL could exert only at an added dosage. Thus both the drugs were capable of interfering in cell proliferation and induce cell mortality at various concentrations. The cells that underwent programmed cell death appeared floating in the culture medium as they lost their adhering property and most of the cells got detached from the surface of the culture plates. Anoikis - early detachment from their basal membrane is one of the prime features observed in monolayer adherent cells during apoptosis [24]. The morphological changes on the apoptotic cell surfaces indicates that whatever apoptosis induction may be initiated, once if the apoptosis begins, the cells starts to follow similar morphological changes [25]. Cells that underwent apoptosis revealed typical features such as membrane blebbing, nuclear condensation, formation of pyknotic bodies and chromatin cleavage [14]. These distinctive hallmark morphological features are widely used for identification and quantification of apoptosis [15]. Therefore, determination of the morphological changes to define apoptosis was visualized using inverted phase contrast microscope. On delayed hours of exposure of $\mathrm{KB}$ cells with the test formulations, they underwent necrosis which was evaluated based on changes that affected the plasma membrane [26], the present study forwarded to analyze the morphological changes cytologically using Propidium iodide (PI) via fluorescence microscope. The dye is permeable to cell nuclei and is useful to identify chromatin condensation and fragmentation in the apoptotic cell nuclei. The red fluorescence emitting propidium iodide is a cell impairment DNAbinding dye which means the dye entry is qualified only when there is decrease in sturdiness and increase in porosity of the plasma membrane [27]. As observed in control or untreated cells appeared to be intact in oval shape and the nuclei appeared less fluorescent or absence of red fluorescence. Necrotic cells were swollen and possess irregular membranes and fluorescent bright pink stained chromatin. Due to weak membrane integrity, PI seeped into intact, even shrunken cells 
and apoptotic dead cell nuclei which emitted bright pink on condensed and fragmented chromatin [24].

Most of the chemotherapeutic agents used in cancer treatment induce a gene regulated phenomenon called apoptosis which in turn induces in chromatin condensation, nuclear shrinkage, membrane blebbing and oligonucleosomal DNA fragmentation [28,29]. The dye acridine orange surpasses into all the cells and makes the nuclei appear green, whereas ethidium bromide stains the nuclei red only when the integrity of cytoplasmic boundary is lost [30]. Thus only live cells display normal green nucleus. Early apoptotic cells with fragmented or condensed chromatin revealed bright green nucleus while late apoptotic cells appeared condensed orange chromatin fragments, whereas cells that have died from direct necrosis display themselves with normal orange nucleus [31]. The results of $\mathrm{AO} / \mathrm{EB}$ staining also exhibited a high number of apoptotic cells on treatment with MVL, NMVL compared with control cells. The increased ROS levels and depletion in ATP changes in NMVL might be a reason for the apoptotic morphological changes were reported by Zorov et al. [32]. Another major add on factor could be NMVL constitutes heavy metals such as mercury and sulfur in its ingredients which could have initiated sustained release, exerting a higher percentage of apoptotic cells $[33,34]$

\section{Conclusion}

Thus, it can be concluded that in this preliminary study by research analysis, the use of MVL and NMVL has caused a remarkable effect in oral cancer lines within short duration (24 hours treatment) and minimal $\mathrm{IC}_{50}$ concentrations. Therefore, bothMVL and NMVL have naturally occurring antioxidants which has the ability to induce apoptosis possibly through caspase-3 intrinsic signaling pathway. Further, MVL, NMVL holds great promise for the use in chemopreventive and chemotherapeutic strategies. Nevertheless, further investigations are necessary to validate its therapeutic claims to determine its effects in in-vivo models also.

\section{Acknowledgments}

I would like to express my sincere and profound thanks to my former guide Prof. Dr. M. Chandrasekar, MD, D.A, Professor and Head (former), MMCH and RI for giving the idea of spark to carry out this research topic.

\section{References}

1. Sultana J, Bashar A, Molla MR (2014) New management strategies of oral tongue cancer in Bangladesh. J Maxillofac Oral Surg 13: 394-400. [Crossref]

2. Coelho KR (2012) Challenges of the oral cancer burden in India. $J$ Cancer Epidemiol 2012: 701932. [Crossref]

3. Rath GK, Gandhi AK (2014) National cancer control and registration program in India. Indian J Med Paediatr Oncol 35: 288-290.

4. Wu IC, Lu CY, Kuo FC, Tsai SM, Lee KW, et al. (2006) Interaction between cigarette, alcohol and betel nut use on esophageal cancer risk in Taiwan. Eur J Clin Invest 36: 236-241.

5. Dev A, Sundararajan V, Sievert W (2004) Ethnic and cultural determinants influence risk assessment for hepatitis C acquisition. J Gastroenterol Hepatol 19: 792-798. [Crossref]

6. Markopoulos AK (2012) Current aspects on oral squamous cell carcinoma. Open Dent J 6: 126-130. [Crossref]

7. Mishra J, Drummond J, Quazi SH, Karanki SS, Shaw JJ, et al. (2013) Prospective of colon cancer treatments and scope for combinatorial approach to enhanced cancer cell apoptosis. Crit Rev Oncol Hematol 86: 232-250.
8. Bremnes RM, Andersen K, Wist EA (1995) Cancer patients, doctors and nurses vary in their willingness to undertake cancer chemotherapy. Eur J Cancer 31A: 19551959.

9. Hakkim PM, Abdullah S (1995) AnubogaVaithyaNavaneethaam - Part VIII. Thamaraipathipagam, Chennai, pp: 96.

10. Safadi FF, Xu J, Smock SL, Kanaan RA, Selim AH, et al. (2003) Expression of connective tissue growth factor in bone: its role in osteoblast proliferation and differentiation in vitro and bone formation in vivo. J Cell Physiol 196: 51-62.

11. SirpuNatesh N, Arumugam M, Karanam G (2018) Apoptotic role of marine sponge symbiont Bacillus subtilis NMK17 through the activation of caspase- 3 in human breast cancer cell line. Mol Biol Rep 45: 2641-2651.

12. Abhishek SNN, Kumar AM (2019) A novel apoptosis inducing metabolite isolated from marine sponge symbiont Monascus sp. NMK7 attenuates cell proliferation, migration and ROS stress-mediated apoptosis in breast cancer cells. RSC Adv 9: 5878-5890.

13. Rasola A, Geuna M (2001) A flow cytometry assay simultaneously detects independent apoptotic paramets. Cytometry 45: 151-157.

14. Moongkarndi P, Kosem N, Kaslungka S, Luanratana O, Pongpan N, et al. (2004) Antiproliferation, antioxidation and induction of apoptosis by Garcinia mangostana (mangosteen) on SKBR3 human breast cancer cell line. Journal of Ethnopharmacology 90: 161-166.

15. Brady HJM (2004) Apoptosis methods and protocols. Human Press, Totowa, NJ, USA.

16. Ziegler UP (2004) Morphological features of cell death. News in Physiological Sciences 19: 124-128.

17. Ahirrao YA, Patil DA (2010) Indigenous healthcare practices in Bhidhana district (Maharashtra). Indian Journal of Natural Products and Resources 1: 85-88.

18. Goldenberg D (2002) Maté: a risk factor for oral and oropharyngeal cancer. Oral Oncol 38: 646-649. [Crossref]

19. Guha N, Boffetta P, Wnsch Filho V, Eluf Neto J, Shangina O, et al. (2007) Oral health and risk of squamous cell carcinoma of the head and neck and esophagus: results of two multicentric case-control studies. Am J Epidemiol 166: 1159-1173. [Crossref]

20. Manickavasagam R, Kumaranandham I (2016) Evaluation of safety of few Serankottai (Semecarpusanacardium) based siddhamedicines. IJAR 11: 162-163.

21. Simna SP, Umadevi S, Gopi V, Elangovan V (2012) Toxicological assessment of herbomineral siddha formulation: Neraadimuthuvallathy Mezhugu in Swiss albino mice. JPR 5: 1684-1689.

22. Simna SP, Elangovan V (2012) Chemo preventive effect of Neraadimuthuvallathy Mezhugu - Siddha formulation against 7,12, DMBA induced Skin Carcinogenesis in swiss albino mice. JPR 5: 4307-4312.

23. Saraswathy A, Mohan GR, Veluchamy G (1999) Chemical analysis of MakaVallatillekiyam. Journal of Research in Ayurveda and Siddha XIX.

24. Frisch SM, Screaton RA (2001) Anoikis mechanisms. Curr Opin Cell Biol 13: 555-562. [Crossref]

25. Reed JC (2000) Mechanisms of apoptosis. Am J Pathol 157: 1415-1430. [Crossref]

26. Elmore S (2007) Apoptosis: a review of programmed cell death. Toxicol Pathol 35: 495-516. [Crossref]

27. DiBartolomeis SM, Moné JP (2003) Apoptosis: a four-week laboratory investigation for advanced molecular and cellular biology students. Cell Biol Educ Winter 2: 275295.

28. Wlodkowic D, Skommer J, Darzynkiewicz Z (2009) Flow cytometry-based apoptosis detection. Methods Mol Biol 559: 19-32. [Crossref]

29. Yakovlev AG, Faden AI (2004) Mechanisms of neural cell death: Implications for development of neuroprotective treatment strategies. NeuroRx 1: 5-16.

30. Franklin WA, Locker JD (1981) Ethidium bromide: a nucleic acid stain for tissue section. J Histochem Cytochem 29: 572-576. [Crossref]

31. Nishikawa S, Sasaki F (1995) DNA localization in nuclear fragments of apoptoticameloblasts using anti-DNA immunoelectron microscopy: programmed cell death of ameloblasts. Histochem Cell Biol 104: 151-159.

32. Zorov DB, Juhaszova M, Sollott SJ (2014) Mitochondrial reactive oxygen species (ROS) and ROS-induced ROS release. Physiol Rev 94: 909-950. 
33. Morcillo P, Esteban MÁ (2016) Cuesta A. Heavy metals produce toxicity, oxidative stress and apoptosis in the marine teleost fish SAF-1 cell line. Chemosphere 144: 225233.
34. Choi JA, Kim JY, Lee JY, Kang CM, Kwon HJ, et al. (2001) Induction of cell cycle arrest and apoptosis in human breast cancer cells by quercetin. Int J Oncol 19: 837-844. [Crossref]

Copyright: ( 2019 Ganapathy P. This is an open-access article distributed under the terms of the Creative Commons Attribution License, which permits unrestricted use, distribution, and reproduction in any medium, provided the original author and source are credited. 